Ahmad Rathomi / Ta'dib: Jurnal Pendidikan Islam, Vol. 8 No. 1 (2019) 000-000

ISSN 1411-8173 | E-ISSN 2528-5092

https://ejournal.unisba.ac.id/index.php/tadib/article/view/4315

\title{
PEMBELAJARAN BAHASA ARAB MAHARAH QIRA'AH MELALUI PENDEKATAN SAINTIFIK
}

\author{
Ahmad Rathomi \\ Fakultas Tarbiyah dan Ilmu Keguruan \\ Insitut Agama Islam Sultan Muhammad Syafiuddin Sambas \\ Jalan Raya Sejangkung No.126 Kawasan Pendidikan Sebayan Sambas \\ E-mail: rathomy.ahmad1207@gmail.com \\ DOI: $10.29313 /$ tjpi.v8i1.4315 \\ Accepted: July 3th, 2019. Approved: October 9th, 2019. Published: October 10th, 2019
}

\begin{abstract}
Talking about innovation will never be finished. Innovations are often carried out both in person, institutions and even at the national level policy stage. The change in the national education curriculum from KTSP to the 2013 Curriculum is a form of innovation in the world of national education. The Ministry of National Education certainly hopes that all formal education practitioners in schools can adopt the 2013 curriculum innovation. Practically, this policy raises problems for teachers, namely implementing the 2013 curriculum which one of the characteristics is learning activities based on the scientific approach. Problems with the implementation of the 2013 curriculum also have an impact on learning Arabic. Therefore, this paper attempts to describe the learning activities of Arabic, especially on the topic of reading skills, through a scientific approach.
\end{abstract}

Keywords: Learning; Scientific Approach; Reading Skills.

\begin{abstract}
Abstrak
Berbicara tentang inovasi seakan tidak akan pernah selesai. Inovasi sering dilakukan baik secara personal, lembaga babkan sampai pada tabap kebijakan dengan skala nasional. Perubaban kurikulum pendidikan nasional dari KTSP menjadi Kurikulum 2013 merupakan bentuk inovasi dalam dunia pendidikan berskala nasional. Kementerian pendidikan nasional tentunya berharap selurub praktisi pendidikan formal di sekolah-sekolah dapat mengadopsi inovasi kurikulum 2013. Secara praktis, kebijakan ini menimbulkan permasalahan bagi guru, yaitu mengimplementasikan kurikulum 2013 yang salah satu karakteristiknya adalah kegiatan pembelajaran berdasarkan pendekatan saintifik. Permasalahan penerapan kurikulum 2013 juga berdampak pada pembelajaran bahasa Arab. Maka dari itu, tulisan ini berusaha untuk mendeskripsikan kegiatan pembelajaran bahasa Arab, khususnya pada maharah qira'ah, melalui pendekatan saintifik.
\end{abstract}

Kata Kunci: Pembelajaran; Pendekatan Saintifik; Maharah Qira'ah. 


\section{PENDAHULUAN}

Inovasi merupakan proses yang harus dilakukan dalam berbagai aspek kehidupan, termasuk kegiatan pendidikan. Bentuk inovasi dalam bidang pendidikan yang dilakukan diantaranya pada aspek kurikulum, yaitu perubahan dari Kurikulum Tingkat Satuan Pendidikan (KTSP) menjadi Kurikulum 2013 (K13). Perubahan kurikulum ini bertujuan untuk meningkatkan mutu pendidikan di Indonesia.

$$
\text { Penerapan kurikulum } 2013
$$

berdampak pada perubahan pola pembelajaran yang dilakukan. Perubahan yang paling jelas adalah pada aspek langkahlangkah pembelajaran, yaitu dengan menerapkan pendekatan saintifik. Implementasi pendekatan saintifik diharapkan dapat memberikan variasi dalam proses pembelajaran sehingga dapat meningkatkan motivasi siswa yang nantinya berdampak pada pencapaian tujuan pembelajaran dan mutu pendidikan nasional.

Implementasi pendekatan saintifik sebagai sikap responsif terhadap inovasi kurikulum pendidikan di Indonesia berpotensi memunculkan permasalahan terutama pada aspek adopsi inovasi kegiatan pembelajaran tersebut. Masalah tersebut dapat disebabkan oleh kemudahan dan keterbiasaan cara mengajar konvensional yang digunakan oleh guru selama ini. Selain itu pemahaman yang kurang utuh terhadap tahapan-tahapan pendekatan saintifik dalam proses pembelajaran juga menjadi penyebab masalah implementasinya.

Pendekatan saintifik pada dasarnya mengacu pada kegiatan ilmiah. Daryanto (2014: 52) mengungkapkan bahwa pembelajaran dengan pendekatan saintifik adalah proses pembelajaran yang dirancang sedemikian rupa agar peserta didik secara aktif mengkonstruksi konsep, hukum atau prinsip melalui tahapan-tahapan mengamati, merumuskan masalah, merumuskan hipotesis mengumpulkan data, menarik kesimpulan dan mengkomunikasikan konsep, hukum atau prinsip yang ditemukan. Majid (2014: 211) mengungkapkan bahwa implementasi pendekatan saintifk dalam pembelajaran meliputi tahapan mengamati, menanya, mencoba, mengolah, menyajikan, menyimpulkan dan mencipta. Dari definisi yang diungkapkan tersebut dapat ditemukan bahwa kegiatan ilmiah yang dilakukan pada proses pembelajaran adalah mengamati atau mengobservasi, menanya, mencoba, menyimpulkan dan mengkomunikasikan.

Implementasi pendekatan saintifik diterapkan di setiap mata pelajaran pada sekolah, diantaranya pembelajaran bahasa Arab. Dikaitkan dengan urgensi pembahasan yang diungkapkan sebelumnya, maka dua hal tersebutlah yang melatarbelakangi tulisan ini. Tulisan ini dibuat dengan harapan dapat memberikan gambaran kepada pembaca terkait dengan prosedur atau langkah-langkah pembelajaran bahasa Arab dengan menggunakan pendekatan saintifik, dalam kesempatan ini lebih difokuskan pada pembelajaran bahasa Arab maharah qira'ah.

Maharah qira'ah merupakan aspek keterampilan yang ingin dicapai dalam pembelajaran Bahasa Arab selain maharah istima' (keterampilan menyimak), maharah kalam (kemahiran berbicara) dan maharah kitabah (keterampilan menulis). Pembelajaran maharah qira'ah diajarkan setelah pembelajaran maharah istima' dan maharah kalam. Secara umum, siswa dianggap memiliki kemampuan maharah qira'ah apabila ia mampu membaca teks bahasa Arab sesuai makhraj dan struktur kalimat serta mampu memahami makna kata atau kalimat yang dibaca.

\section{PEMBAHASAN}

\section{Pendekatan Saintifik}

Pendekatan saintifik merupakan salah satu pendekatan pembelajaran ilmiah. M. Hosnan (2014: 34) mengungkapkan bahwa pendekatan saintifik merupakan 
suatu proses pembelajaran yang dirancang agar peserta didik secara aktif mengkonstruksi konsep, hukum, atau prinsip melalui kegiatan mengamati, merumuskan masalah, mengajukan atau merumuskan hipotesis, mengumpulkan data dengan berbagai teknik, menganalisis data, menarik kesimpulan, dan mengkomunikasikan. Sedangkan menurut Daryanto (2014: 51), pembelajaran dengan pendekatan saintifik adalah proses pembelajaran yang dirancang sedemikian rupa agar peserta didik secara aktif mengkonstruksi konsep, hukum atau prinsip melalui tahapan-tahapan mengamati, merumuskan masalah, mengajukan atau merumuskan hipotesis, mengumpulkan data dengan berbagai teknik, menganalisis data, menarik kesimpulan dan mengkomunikasikan konsep, hukum atau prinsip yang ditemukan.

Dari definisi di atas dapat dicermati bahwa pendekatan santifik merupakan salah satu pembelajaran yang berpusat pada siswa dengan menekankan partisipasi dan keaktivan siswa. Melalui pertisipasi dan keaktivan tersebut diharapkan siswa dapat mengenal dan memahami konsep melalui proses penarikan kesimpulan. Pendekatan saintifik dimaksukan untuk memberikan pemahaman kepada peserta didik dalam mengenal, memahami berbagai materi menggunakan pendekatan ilmiah. Penerapan pendekatan saintifik dalam pembelajaran melibatkan keterampilan proses seperti mengamati, mengklasifikasi, mengukur, meramalkan, menjelaskan, dan menyimpulkan.

Setiap pendekatan memiliki tujuan khusus. Majid (2014: 193) mengungkapkan bahwa penerapan pendekatan saintifik bertujuan untuk memberikan pemahaman kepada peserta didik dalam mengenal, memahami berbagai materi menggunakan pendekatan ilmiah, bahwa informasi bisa berasal dari mana saja, kapan saja, tidak bergantung pada informasi searah dari guru. Hosnan (2014: 34-37) mengemukakan bahwa implementasi pendekatan saintifik bertujuan untuk meningkatkan kemampuan berpikir peserta didik, membentuk kemampuan dalam menyelesaikan masalah secara sistematik, menciptakan kondisi pembelajaran supaya peserta didik merasa bahwa belajar merupakan suatu kebutuhan, melatih peserta didik dalam mengemukakan ide-ide, meningkatkan hasil belajar peserta didik, dan mengembangkan karakter peserta didik.

Implementasi pendekatan saintifik dalam pembelajaran intinya bertujuan melibatkan keterampilan proses seperti mengamati, mengklasifikasi, mengukur, meramalkan, menjelaskan, dan menyimpulkan. Dalam melaksanakan proses proses tersebut, bantuan guru diperlukan. Akan tetapi bantuan guru tersebut harus semakin berkurang dengan semakin bertambah dewasanya peserta didik atau semakin tingginya kelas peserta didik. Daryanto (2013: 55) mengungkapkan bahwa pembelajaran berbasis pendekatan ilmiah itu lebih efektif hasilnya dibandingkan dengan pembelajaran tradisional. Hasil penelitian membuktikan bahwa pada pembelajaran tradisional, retensi informasi dari guru sebesar $10 \%$ setelah 15 menit dan perolehan pemahaman kontekstual sebesar 25\%. Pada pembelajaran berbasis pendekatan ilmiah, retensi informasi dari guru sebesar lebih dari $90 \%$ setelah dua hari dan perolehan pemahman kontekstual sebesar 50-70\%.

Pendekatan saintifik erat kaitannya dengan metode saintifik. Metode saintifik pada umumnya melibatkan kegiatan pengamatan yang dibutuhkan untuk merumuskan hipotesis. Metode ilmiah dilandasi dengan pemaparan data yang diperoleh melalui pengamatan atau percobaan. Sani (2015: 51) mengungkapkan bahwa aktivitas yang dilakukan dalam kegiatan ilmiah pada umumnya dapat dilihat pada gambar berikut ini: 
Gambar 2.1

Komponen Aktivitas Ilmiah

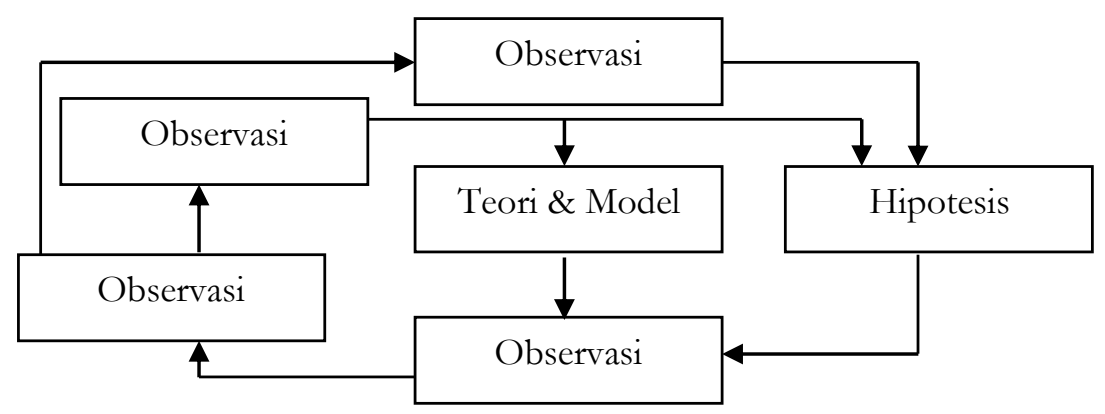

Pembelajaran dengan pendekatan saintifik menurut Sani (2015: 53) memiliki tahapan proses pembelajaran, yaitu mengamati, menanya, menalar atau mengasosiasi, mencoba atau mengumpulkan informasi dan mengkomunikasikan. Tahapan aktivitas belajar yang dilakukan dengan pendekatan saintifik tidak harus mengikuti prosedur yang kaku, namun disesuaikan dengan materi yang akan dipelajari.

1. Melakukan Pengamatan atau Observasi Sani (2015: 54) mengungkapkan bahwa observasi adalah menggunakan panca indera untuk memperoleh informasi. Suatu obyek dapat diobservasi untuk mengetahui karakteristiknya, seperti warna, bentuk, suhu, volume, berat, bau suara, tekstur dan lain-lain. Perilaku manusia juga dapat diobservasi untuk mengetahui sifat, kebiasaan, respon, pendapat dan karakteristik lainnya.

Langkah pembelajaran dengan observasi memiliki keunggulan diantaranya menyajikan media obyek secara nyata, siswa senang dan termotivasi. Daryanto (2014: 60) mengemukakan bahwa mengamati sangat bermanfaat bagi pemenuhan rasa ingin tahu siswa, sehingga proses pembelajaran memiliki kebermaknaan yang tinggi.
2. Menanya

Siswa perlu dilatih untuk merumuskan pertanyaan terkait dengan topik yang akan dipelajari. Aktivitas belajar ini sangat penting untuk meningkatkan keingintahuan dalam diri siswa dan mengembangkan kemampua mereka untuk belajar sepanjang hayat. Guru dapat mengajukan beberapa pertanyaan dalam upaya memotivasi siswa dalam merumuskan pertanyaan. Daryanto (2014: 65) mengungkapkan bahwa guru yang efektif mampu menginspirasi siswa untuk meningkatkan dan mengembangkan ranah sikap, keterampilan, dan pengetahuannya.

3. Menalar

Kemampuan mengolah informasi melaui penalaran dan berpikir rasional merupakan kompetensi penting yang harus dimiliki oleh siswa. Informasi yang diperoleh dari pengamatan atau percobaan yang dilakukan harus diproses untuk menemukan keterkaitan satu informasi dengan informasi lainnya, menemukan pola dari keterkaitan informasi, dan mengambil berbagai kesimpulan dari pola yang ditemukan.

Kegiatan menalar menurut Permendikbud Nomor 81a Tahun 2013 (dalam Daryanto, 2014: 70) adalah memproses informasi yang sudah dikumpulkan baik terbatas dari hasil 
kegiatan mengumpulkan atau eksperimen maupun hasil dan kegiatan mengumpulkan informasi. Kegiatan ini dilakukan untuk menemukan keterkaitan satu informasi dengan informasi lainnya, menemukan pola dari keterkaitan informasi tersebut. Kompetensi yang dapat dikembangkan melalui kegiatan ini yaitu sikap jujur, teliti, disiplin, taat aturan, kerja keras, kemampuan menerapkan prosedur, dan kemampuan berpikir induktif serta deduktif dalam menyimpulkan.

4. Mencoba

Belajar dengan kegiatan ilmiah melibatkan siswa untuk melakukan aktivitas penyelidikan terhadap fenomena yang telah diamati dalam upaya menjawab suatu permasalahan. Guru juga dapat menugaskan siswa untuk mengumpulkan informasi dari berbagai sumber. Hasil belajar yang nyata atau otentik akan didapat bila siswa mencoba atau melakukan percobaan. Daryanto (2014: 78) mengungkapkan bahwa aplikasi mencoba atau eksperimen dimaksudkan untuk mengembangkan berbagai ranah tujuan belajar, yaitu sikap, keterampilan, dan pengetahuan.

\section{Mengkomunikasikan}

Kegiatan mengomunikasikan merupakan kegiatan yang mana guru memberikan kesempatan kepada peserta didik untuk menyampaikan apa yang telah dipelajari baik dengan cara ditulis maupun diceritakan. Melalui kegiatan ini, maka guru dapat memberikam konfirmasi jika ada kesalahan pemahaman peserta didik. Hosnan (2014: 37) mengungkapkan bahwa kompetensi yang diharapkan dapat berkembang dari kegiatan ini adalah sikap jujur, teliti, toleransi, kemampuan berpikir sistematis, mengungkapkan pendapat dengan singkat dan jelas, serta mengembangkan

berbahasa yang baik dan benar.

\section{Pembelajaran Bahasa Arab Maharah Qira'ah}

Membaca merupakan kemahiran berbahasa yang kegiatan latihannya dilakukan setelah latihan kemahiran berbicara. Secara umum, kegiatan membaca merupakan proses komunikasi antara pembaca dengan penulis melalui teks bacaan. Hermawan (2013: 143) kemampuan mengenali dan memahami isi sesuatu yang tertulis (lambang-lambang tertulis) dengan melafalkan dan mencernanya di dalam hati. Definisi tersebut mengindikasikan bahwa kemahiran berbicara mengandung dua aspek yaitu, mengubah lambang tulis menjadi lambang bunyi dan menangkap makna dari seluruh situasi yang dilambangkan dengan lambang-lambang tulis dan bunyi tersebut. Aspek yang kedua merupakan inti dari kegiatan membaca tanpa mengabaikan aspek pertama karena aspek pertama mendasari kemahiran kedua.

Kemampuan membaca teks Arab sangat bergantung pada pemahaman si pembaca terhadap qawaid atau gramatika dalam bahasa Arab. Gramatika tersebut meliputi ilmu nabwn (sintaksis) dan sharaf (morfologi). Kemampuan ini akan sangat mempengaruhi pembaca dalam memahami isi atau arti dari yang dibaca. Maka dari itu, urutan dalam kemahiran membaca bukanlah membaca untuk memahami, akan tetapi memahami gramatika terlebih dahulu baru bisa membaca teks dengan benar.

Kemahiran siswa dalam membaca teks Arab dapat dilihat dari beberapa indikator, sebagaimana yang diungkapkan Amin Santoso (2011: 55) yaitu; (1) membunyikan huruf, kata dan kalimat yang terdapat dalam teks qira'ab; (2) mengenali struktur kalimat, dengan memberi syakal pada huruf, kata dan kalimat yang terdapat dalam teks qira'ah; dan (3) menemukan makna dari teks yang dibaca. Artinya seorang siswa dapat dikatakan memiliki kemahiran membaca yang baik apabila 
setelah dilakukan evaluasi ia dapat melakukan ketiga indikator tersebut dengan baik. Sebaliknya, jika siswa tidak dapat melakukan ketiga indikator di atas, maka dapat dikatakan ia belum memiliki kemahiran membaca sebagaimana tujuan pembelajaran membaca.

Kegiatan pembelajaran maharab qira'ah disesuaikan dengan tujuan dan indikator pencapaian. Dalam pembelajarannya, al-Ghali dan Abdullah (2012: 38) menekankan kepada guru untuk memperhatikan beberapa aspek dalam latihan-latihan membaca, yaitu; membunyikan huruf dengan benar sesuai makhraj dan membedakan bunyi huruf yang mirip dan berdekatan dalam pelafalan; (2) menghubungkan lambang dengan makna; (3) memahami bacaan secara global dan rinci; (4) gerakan mata yang benar dan tepat; (5) membedakan hamzah washal dan hamzah qatha'; (6) memperhatikan harakat panjang dan pendek; (7) tidak salah membaca atau mengganti huruf dengan lainnya; (8) tidak menambah-nambah huruf di luar huruf aslinya; (9) tidak menghilangkan salah satu huruf aslinya; (10) memperhatikan tempat dan waktu jeda; (11) dapat menemukan pikiran utama; (12) membedakan pikiran utama dari pikiran penjelas; (13) menjiwai bacaan; (14) menganalisis yang dibaca; (15) menggunakan intonasi suara sesuai variasi susunan dan kandungan isi; dan (16) tidak mengulang-ulang sebuah kata atau ragu dalam membacanya. Aspek-aspek di atas tentunya perlu menjadi perhatian khusus bagi guru yang akan melatih kemabiran qira'ah siswa.

Latihan kemahiran qira'ah, secara umum menurut Hermawan (2014: 144) terbagi menjadi dua bagian yaitu qira'ab jabriyah dan qira'ah shamitah. Latihan qira'ah jabriyah adalah latihan membaca dengan melafalkan atau menyuarakan simbolsimbol tertulis berupa kata-kata atau kalimat yang dibaca. tujuan latihan ini adalah agar para siswa mampu melafalkan bacaan dengan baik sesuai sistem bunyi dalam bahasa Arab. Latihan membaca jenis ini cocok diberikan kepada pelajar tingkat pemula. Sedangkan latihan qira'ah shamitah adalah latihan membaca dengan tidak melafalkan simbol-simbl tertulis berupa kata-kata atau kalimat yang dibaca, melainkan hanya untuk mengandalkan kecermatan eksplorasi visual. Ulin Nuha (2016: 105) mengungkapkan bahwa qira'ah shamitah adalah membaca dengan cara tidak mengeluarkan ujaran, tetapi cukup di dalam hati. Tujuan latihan yang kedua ini adalah agar siswa menguasai isi bacaan atau memperoleh informasi sebanyak-banyaknya tentang isi bacaan dalam waktu yang cepat.

Dalam mencapai tujuan
pembelajaran qira'ah, guru bahasa Arab harus memberikan latihan dalam pembelajaran yang disesuaikan dengan indikator pencapaian. Amin Santoso (2011: 59) menjelaskan bahwa langkah-langkah pembelajaran maharah qira'ah dapat dilakukan dengan langkah-langkah sebagai berikut; (1) siswa melafalkan kata, frase dan kalimat yang terdapat dalam teks sesuai makhraj; (2) siswa membaca materi qira'ah sesuai struktur kalimat yang benar; (3) siswa mengidentifikasi struktur kalimat; (4) siswa mengidentifikasi makna kata, frasa dan kalimat dalam teks; (5) siswa menjawab pertanyaan tentang teks qira'ab; (6) siswa membaca dalam hati teks qira'ah; (7) siswa memahami pesan yang terdapat dalam teks qira'ah.

Ketercapaian tujuan pembelajaran qira'ah dapat diketahui dengan melakukan evaluasi. Tes sebagai teknik dalam pengukuran dan penilaian suatu pembelajaran harus disesuaikan dengan tujuan pembelajaran itu sendiri. Maka dari itu, soal-soal yang dibuat untuk mengukur maharah qira'ah siswa juga mengarah kepada indikator pencapaiannya. Adapun model tes maharah qira'ah adalah: (1) tes membunyikan huruf sesuai makhraj; (2) tes mengidentifikasi struktur kalimat; (3) tes menemukan makna teks yang dibaca. 


\section{Pembelajaran Maharah Qira'ah dengan Pendekatan Saintifik}

Mengacu pada penjelasan sebelumnya, maka integrasi pendekatan saintifik dalam pembelajaran bahasa Arab maharah qira'ah dilakukan dengan langkahlangkah berikut ini:

1. Tahapan Mengamati

Tahapan mengamati merupakan langkah awal dalam pembelajaran dengan pendekatan saintifik. Pada tahapan ini siswa melakukan pengamatan terhadap suatu obyek yang berkaitan dengan materi pelajaran. Maka dari itu, pembelajaran maharah qira'ah tahapan ini dapat dilakukan dengan:

a. Guru meminta siswa untuk menyimak bacaan guru

b. Guru membaca teks qira'ah dengan suara yang jelas sesuai makhraj. Kegiatan ini dilakukan untuk mencontohkan bacaan yang benar. Dalam membaca, guru sebaiknya membaca tidak terlalu cepat dan menekankan panjang pendek huruf dan tempat berhenti/jeda membaca (waqaf).

Pada tahapan ini, siswa hanya diminta untuk menyimak bacaan guru tanpa mengikuti bacaan guru.

2. Tahapan Menanya

Pada tahapan ini siswa diminta untuk mengajukan beberapa pertanyaan atau mengungkapkan pernyataan terkait dengan cara membaca, makna kosakata atau sturktur bahasa yang akan dipelajari. Guru sebaiknya menerapkan teknik dan taktik tertentu dalam menstimulus siswa agar berani dan percaya diri untuk bertanya atau mengungkapkan pikiran. Selain siswa, guru juga dapat mengajukan beberapa pertanyaan kepada siswa terkait makna kata dan struktur bahasa. Adapun langkah pembelajaran yang dapat dilakukan pada tahap ini adalah:

a. Guru bertanya kepada siswa tentang makna kata pada teks yang lazim digunakan atau yang telah dipelajari pada pertemuan sebelumnya.

b. Guru meminta siswa untuk menanyakan kosakata yang tidak diketahui maknanya.

c. Guru bertanya tentang struktur dan kaidah yang terintegrasi dalam teks qira'ah.

3. Tahapan Menalar

Tahapan menalar dapat dilakukan dengan meminta siswa untuk mengidentifikasi struktur bahasa yang dipelajari dan menterjemahkan teks. Melalui kegiatan ini siswa dilatih untuk berpikir. Adapun langkah pembelajaran yang dilakukan adalah:

a. Siswa ditugaskan untuk membaca dalam hati (qira'ah shamitah) dan menerjemahkan teks qiraah, kalimat demi kalimat.

b. Siswa diminta untuk menemukan ide pokok dalam teks qira'ah.

c. Guru menjelaskan struktur dan kaidah bahasa yang terintegrasi di dalam teks qira'ah.

d. Siswa ditugaskan untuk mencari struktur dan kaidah bahasa yang dipelajari.

4. Tahapan Mencoba

Kegiatan pembelajaran pada tahapan mencoba adalah untuk memberikan pengalaman kepada siswa melakukan suatu kegiatan sehingga tercapai keterampilan yang diharapkan. Dalam pembelajaran bahasa Arab, khususnya maharah qira'ah, siswa diminta untuk membaca teks qira'ah sesuai makhraj dan struktur bahasa. Adapun langkah pembelajaran pada tahap ini adalah:

a. Guru meminta siswa untuk membaca teks qira'ah dengan suara nyaring (qira'ah jahriyah). Kegitan ini dapat dilakukan secara bersamasama, atau meminta siswa satu per satu.

b. Guru meminta siswa menyebutkan terjemahan beberapa kata dan kalimat yang dibaca. 
c. Guru memberikan latihan kepada siswa untuk memberi syakal pada teks yang sudah disiapkan sebelumnya.

d. Guru meminta siswa untuk membuat kalimat baru sesuai struktur dan kaidah yang dipelajari.

5. Tahapan Mengkomunikasikan

Pada tahapan ini siswa diminta untuk menyampaikan isi kandungan teks qira'ah yang telah dipelajari. Siswa dapat ditugaskan untuk menuliskan pemahaman mereka terhadap teks qira'ah di buku latihan masing-masing. Selanjutnya, siswa diminta untuk maju ke depan kelas untuk menyampaikan pemahaman mereka terhadap teks qira'ah yang telah ditulis.

Langkah-langkah pembelajaran yang diungkapkan di atas harus dilakukan secara sistematis karena itulah esensi dalam pendekatan saintifik, kegiatan pembelajaran yang mengintegrasikan langkah-langkah penelitian ilmiah.

\section{KESIMPULAN}

Implementasi pendekatan saintifik dalam pembelajaran bahasa Arab di era sekarang merupakan suatu keharusan sebagai sebuah inovasi dalam dunia pembelajaran bahasa Arab. Selain karena tuntutan kurikulum pendidikan nasional, juga agar terciptanya sebuah variasi metode pembelajaran bahasa Arab dalam konteks teoritis maupun praktis. Langkah-langkah pembelajaran bahasa Arab maharah qira'ah dengan pendekatan saintifik terdiri dari lima tahapan, yaitu (1) menyimak bacaan; (2) menanyakan makna kosakata dan struktur bahasa; (3) menemukan ide pokok teks dan struktur bahasa; (4) latihan membaca teks dan memberi syakal; dan (5) menyampaikan pemahaman siswa terhadap teks qira'ah.

\section{DAFTAR PUSTAKA}

Hosnan, M. (2014). Pendekatan Saintifik dan Kontekstual dalam Pembelajaran Abad 21. Bogor: Ghalia Indonesia.

Daryanto. (2014). Pendekatan Pembelajaran Saintifik 2013. Yogyakarta: Gava Media.

Majid, Abdul. (2014). Strategi Pembelajaran. Bandung: Remaja Rosdakarya.

Sani, Ridwan Abdullah. (2015). Pembelajaran Saintifik untuk Implementasi Kurikulum 2013. Jakarta: Bumi Aksara.

Susanto, Ahmad. (2013). Teori Belajar dan Pembelajaran di Sekolah Dasar. Jakarta: Kencana Prenada Media Grup.

Santoso, Amin dkk. (2011). Modul Materi Praktikum Mata Kuliah Pembelajaran Bahasa Arab. Pontianak: Sekolah Tinggi Agama Islam Negeri Pontianak.

Hermawan, Acep. (2014). Metodologi Pembelajaran Babasa Arab. Bandung: Remaja Rosdakarya.

Nuha, Ulin. (2016). Ragam Metodologi \& Media Pembelajaran Bahasa Arab. Yogyakarta: DIVA Press.

Al-Ghali, Abdullah \& Abdullah, Abdul Hamid. (2012). Menyusun Buku Ajar Babasa Arab. Padang: Akademia Permata. 